\title{
New Testament Textual Criticism is dead! Long live New Testament Textual Criticism!
}

\author{
J Eugene Botha \\ Department of New Testament \\ University of South Africa
}

\begin{abstract}
This article explores the notion that some of the basic assumptions upon which textual criticism is built, like the quest for an "original text", have serious flaws and that much of what has been attempted the last $\mathbf{3 0 0}$ years is actually an exercise in futility. In this sense New Testament textual criticism can be declared dead. However, textual criticism, if viewed from a different perspective, can indeed be reimagined to make a fresh and important contribution to New Testament scholarship.
\end{abstract}

\section{INTRODUCTION}

New Testament Criticism has rightly been called the Cinderella of New Testament studies, because it has been somewhat isolated from the rest of New Testament studies. ${ }^{1}$ For example, in utilizing social science methodologies to read and interpret a text, textual critical aspects do not normally play a part. And textual criticism hardly features in historical Jesus studies or Pauline theology or literary readings of John. This state of affairs is not on account of any concerted effort or deliberate intention to achieve this.

The very nature and practice of textual criticism has led it to become a discipline which seems to exist in isolation from other New Testament endeavours: it has become so specialised and complex that only those with specialised skills and knowledge dare to venture there. It has developed sophisticated methodologies and taxonomies and ways of comparing manuscripts like the Claremont Method of which the vast majority of New Testament scholars know nothing and frankly, don't care. New Testament

\footnotetext{
${ }^{1}$ While it is, of course a generalisation, it does seem that it is somewhat different for other New Testament disciplines: There is much more integration and cross-fertilization possibilities. Textual Criticism tends to be much more isolated.
} 
scholarship taking Greek seriously, use the Greek New Testament texts of Nestle-Aland, the latest being the $27^{\text {th }}$ edition $\left(N A^{27}\right.$ ) or that of the United Bible Societies, the latest being the $4^{\text {th }}$ revised edition (UBSGNT ${ }^{4 \text { rev }}$ or UBS ${ }^{4}$ rev ) and, except where it can help an argument, it seems that they generally accept that the text in these editions is the best and most reliable text to use.

It is also unquestioningly accepted that textual criticism is a necessary and fundamental New Testament endeavour, and while it is very technical, with only specialists working in the field and a bit on its own, it is still valid and a worthwhile undertaking. Its raison d'etre has never been questioned.

This is hardly surprising. Questions are seldom asked about the basic assumptions and presuppositions of theological disciplines like textual criticism, which are considered as fundamental New Testament disciplines and which have been in existence for many hundreds of years. However, we contend here that the time has come to critically examine some these standard disciplines to see if the premises and assumptions upon which they are built, are still valid in the light of the developments in other areas of New Testament studies in recent years, and scholarship in general. In this article we will do just this, and ask some questions about the fundamental assumptions underlying the discipline of New Testament textual criticism. ${ }^{2}$

This line of questioning has been triggered by two things: First, it was the presidential address of Barbara Aland at the SNTS meeting in 2005 in Halle, Germany which was a clear indication that for the majority of textual criticism scholars, among all the other endeavours spawned by the study of ancient manuscripts and variations, the basic assumption was still in place: textual criticism is a quest (still elusive) for the original text of the New Testament. It was a revelation, and a deja vu moment: In the 20 odd years since I have had intensive interaction with textual criticism, and memorised Metzger's the text of the New Testament (which appeared for the first time in 1964), nothing much has changed! It seems that the only things that have changed in recent years are the complexity of the methods of analysis and the appropriation of various computer programmes to make the work done by hand for generations quicker, more reliable and easier. New technology also makes it possible to all to access ancient facsimiles and manuscripts with a click of a mouse button. And the comparison of various text traditions has become much easier. There are marvellous things happening around the interface of ancient manuscript studies and electronic media, but the ultimate

\footnotetext{
${ }^{2}$ Textual criticism has also received critique on other levels, like that of Delobel (2002) in which he point out that the Achilles heel of New Testament textual criticism is the eclecticism present in textual criticism. But this critique id aimed at methodological matters and does not address more fundamental questions presented here based on a book by David Parker (1997).
} 
object of textual criticism has not changed at all. ${ }^{3}$ Do not get me wrong, I have great admiration for textual critics and their skills and sophisticated methodologies, but observing the likes of Barbara Aland talking textual criticism and realising that there is a New Testament discipline which has not seen fundamental changes in decades, and which the vast majority of New Testament scholarship can and are doing without, was a curious experience. Secondly, this line of questioning was triggered by the discovery of a book called The living text of the Gospels by David C Parker (1997). Just as listening to Barbara Aland was a revelation, the book by Parker was also a revelation because it had begun to articulate the unease I have felt with textual criticism for a long time, and the material he presented, to my mind at least, has the potential to rock the foundations of the discipline of textual criticism.

In this article we will take a critical look at the fundamental assumptions of textual criticism, and explore some of the questions Parker brought to the table regarding textual criticism and which can lead one to declare textual criticism as dead. But we will also look at some of the implications this line of questioning implies and how this can lead to a re-imagining and re-discovery of the role of textual criticism in New Testament scholarship. In the end we will ask more questions than we have answers for, but at least it will help us to explore the role and function and even the existence of textual criticism in a way which is long overdue.

\section{THE RECEIVED VIEW}

We need not dwell on this aspect for too long, since all trained in theology would have been confronted with the basics of textual criticism: The so-called received view, since there is no other alternative view yet! The objective of textual criticism has for a long time been seen as recovering the original text. The fundamental idea behind this is the notion that there has been an original text for each and every book of the New Testament and that these originals have been corrupted over the years through intentional and unintentional alterations.

The assumption is that through the correct classification of manuscripts and manuscript tradition, and the careful and well researched selection of variant readings, it is possible to reconstruct the original text. In fact NestleAland texts and the Greek text of the UBS are seen as examples of a text

\footnotetext{
${ }^{3}$ This is not to say that textual criticism has not evolved into a major sub-discipline of its own, with remarkable work being done on individual manuscripts and textual traditions, paleography, and so on. But the initial impetus and raison d'etre from the start was the quest for the original text, or at least a text a close as possible to the one original that existed assumed to have existed.
} 
which is pretty close to "the original". That this is still the way textual criticism is viewed by many scholars and Biblical interpreters, is affirmed by Ellingworth (2000:63): "Students, translators and others whose interest in the Greek text is practical rather than technical may normally work from the presupposition that the lemma of the edition in their hands is 'the original text'; but those who prepare these editions and those who use them more intensively, know better." Even the New York Times bestseller by Ehrman (2006:57) reflect this view: "One of the leading questions that textual critics must deal with, is how to get back to the original text - the text as the author first wrote it - given that our manuscripts are so full of mistakes." And the full title of Bruce Metzger's hugely influential book on textual criticism actually says it all: The text of the New Testament: Its transmission, corruption and restoration. The restoration implied by Metzger is the belief that textual criticism, with its complex array of methodologies and taxonomies and models, will be able to filter out the changes (intentional and unintentional) and voila, we will have arrived at the original version. ${ }^{4}$

This is, of course, putting it rather bluntly, and no serious textual critic will grant that we today actually have the original (see Ellingworth 2000:62; Delobel 2000:3), but it is also clear that this is the ultimate goal implicit in the endeavour. And to achieve this goal, more increasingly complex systems and computer programmes are utilised (see Aland 2005; Parker 1997:xii; 2000). And because the latter endeavour is so specialised and so technical, few Biblical scholars and interpreters actually pay serious attention to textual criticism and it continues in virtual isolation from other theological disciplines.

In this context the book of David Parker (1997) came as a fresh new breeze: it challenges the long held assumptions of textual criticism and began to pave the way of looking differently at and utilising textual criticism in another way. He says in his introduction: "The way in which this undertaking has been set out is to bring together things which are too often kept separate .... Recent developments in biblical criticism have brought new challenges for textual criticism" (Parker 1997:xi).

\section{RE-ASSESSING THE RECEIVED VIEW}

David Parker's book was generally well received (e.g. Head 1997:359-361; Harvey 1998:141-142; Elliott 1999:176-181 and Ellingworth 2000:61-73) while Birdsall (1999:275-288) and Silva (2000:295-302) have had less favourable

\footnotetext{
${ }^{4}$ In addition to the traditional belief that there has been a standard original of the books of the New Testament somewhere out there, there are also other theories like that of Trobish (2000) which postulates that there has not been a long text tradition at all, but that the New Testament was created in a single sweep, thus making the postulation of an "original" much easier. This creation he calls the "canonical edition".
} 
things to say about the book. Parker (1997) presents rather fundamental challenges to traditional textual criticism, so it is really surprising that with the exception of Epp (1999) very few scholars have paid any serious attention to his premises. Parker gives a brief but very succinct overview of the theory and practice of textual criticism and then uses a number of examples to show differences between various versions of New Testament passages. In the last two chapters he reaches some conclusions which are of great significance.

Parker (1997:182-202) argues that two aspects regarding the manuscripts of the New Testament should be taken very seriously. In the first place one should not underestimate the medium in which they were transmitted. They were transmitted as texts, as written and copied texts. "It is with the physical reality of their existence that our interpretation of them must reckon" (Parker 1997:196). They each have a unique history and a unique being. And the second point Parker (1997:196-202) stresses, is that there was a remarkable variation in the text tradition, and this remarkable variation could hold clues to early Christian attitudes to tradition and the communities that created them.

This implies that the texts themselves are not merely the carriers of tradition, but that they are pat of tradition, that they are traditions in themselves (see Parker 1997:209). They are not just handy sources to be used to compile lists of possible lexical variants, they are actually also traditions in themselves. And this should be respected. If this premise is accepted in also means that the texts cannot be used to restore an "original". They were not that kind of texts. They are in themselves witnesses to and part of a tradition that existed a particular point in time. They are in a sense, also "originals", multiple originals. Parker, who is a specialist on Codex Bezae (Parker 1992; Parker \& Amphoux 1996), says that Bezae was an open and free text. It did not exist only as a variation of another prior standard original text, but it existed as an individual, unique document, and should be studied and interpreted as such, and not merely as a source of variant readings for a compilation text like Nestle Aland.

Rather than being the bearers of the flaws of early scribes the various manuscripts, and the incidental tools to get at the original texts, the manuscripts we have are rather to be seen as witnesses to the vibrancy and diversity of the early Christian movement. What we actually have in the variants is testimony to the amazing scribal fluidity at very early stages of the development of these texts, and even after they started a life as written texts. "According to the predominant view, the literary activity of the evangelists marked and end to the fluidity which had hitherto characterised the traditions ... The reconstruction which emerged form the present study is that the text with its variants remained fluid for centuries." (Parker 1997:205). He uses the 
example of harmonisation which is found in the last chapters of Luke and remarks: "That such harmonisations are found centuries after the compilation of the Gospels is incontrovertible evidence that the traditions continued to live, that is, to grow" (Parker 1997:205).

But even talking of "variants" and "variability of fluidity" should be done with care as it immediately conjures up images of a standardised text. And there is no evidence that a notion ever existed in early Christianity that there is one fixed, standard text. There is no evidence that Christian scribes had this idea even when copying manuscripts. This is different from the way in which Hebrew or Masoretic texts were treated: Very early on there was a compulsion to standardise and this can clearly be seen in the manuscript traditions of the Hebrew Bible. The Greek manuscript tradition was much more open and flexible, and did not operate with fixed originals in mind.

Perhaps a reason for this lack of a fixed standard is the origin of the New Testament texts themselves: They were embedded in the Christian tradition which had a long history of oral transmission. Was verbal accuracy or verbatim reportage the aim in the transmission of Jesus traditions? It does not seem to be the case. Orality studies have made it abundantly clear that the oral tradition itself was also fluid and flexible. In orality there is no fixed text. It stands to reason that the early scribal transmission of the tradition would have followed the same flexibility.

What Parker is arguing for is for the re-imagining of the role and function of textual criticism, and to focus less on the search for a fixed original. "Expressed most starkly, the issue is whether the attempt to recover a single original text is consonant with the character of the free-manuscript tradition, or whether it is driven by external demands: In particular those of the churches for authoritative texts ... and of scholars for a sure foundation on which to build their theories" (Parker 1997:209). Another observation that must be raised here is that we know that it was possible for ancient scribes to transmit texts very accurately and precisely. The question we need to ask is why they chose not to do it in this instance. It is perhaps the fact that there has been a long legacy of fluid oral traditions which co-existed with scribal traditions for a long time. A fixed, authoritative version was not the aim ever! But modern textual criticism is seeking for such a text.

The argument made by Parker (1997:ix-xii) and also Kelber (2005:1522) that the early oral and scribal traditions did not operate with a fixed original in mind is gaining ground in New Testament scholarship. In this context Parker starts to speak of "multiple originals". He argues that it is futile to look for a singular fixed original: It simply did not exist. This means that what has been happening in textual criticism for the last 300 years has been based on a wrong assumption. Carried to its radical but logical conclusion, it means that 
Parker has in effect announced the death of textual criticism. It is exists to recover something that never existed!

And this leads one to ask about the status of Nestle-Aland 27 and the UBS 4 New Testament text. The UBS's way of classifying the variant readings in terms of $A, B, C$ and $D$ probabilities has already been challenged (see e.g. Clarke and K Bales 1999:86-93), but more fundamental in the light of Parker's argument is the question: What do we have in front of us when we look at either NA ${ }^{27}$ or $\mathrm{UBS}^{4}{ }^{4 \text { rev }}$ ? It is definitely not the original Greek text: That fact is granted by the editors and everyone else. It is a compilation text constructed on the basis of a wide variety of ancient and medieval manuscripts which have been collected and certain readings chosen of others. It is a modern compilation text, informed by the minds and power plays and insights of a host of specially trained specialists. ${ }^{5}$ It is definitely not the Bible of the living communities of early Christianity. We can be sure that not even one of the documents in the Greek New Testaments we have today is a document that circulated anywhere in the early Christian world. In fact, the Modern Greek New Testament is as "contaminated" by intentional changes, effected by modern electronic age scribes, as any of the manuscripts we have. It is a construction, not a reconstruction of a text that did not exist at any time or at any place, except in the modern era. And the further question that must also be asked is: how much does this text reflect of early Christianity, and how much does it reflect of the modern compilers and the tradition of textual criticism started in modernity? ${ }^{6}$

So the ultimate question is: With what are we confronted with, when we have the Nestle-Aland text in front of us? What is it good for? If one think it

\footnotetext{
${ }^{5}$ In this regard I think it is important that a lot of the traditional New Testament disciplines should also subjected to questions regarding the foundations of the discipline, much in the same way we do here for textual criticism. For example: Many of the so-called Introduction questions can and should be interrogated. Why has it become important for scholars in modernity to know the exact date of a book, or why is the place of origin so very important? It was not important in antiquity and has not been important for abut 1500 years of the existence of the documents. In the modern era is has become important to ask these questions. There is also a need to determine why certain questions have become important in specific eras, and then to ask if those question are still valid and meaningful today.

${ }^{6}$ I surmise behind all of this is the assumption that there was one, homogeneous tradition, which carried the basic doctrine of truth and this tradition was carried forward, first by an oral tradition and then later by a scribal fixation. The assumption is that the texts carry this one singular tradition and that they are the mere vessels that do this. Parker (1997) criticises this view strongly. He says that we have to take the fact that the texts are texts, seriously. They are not mere carriers of traditions they are traditions in and of themselves. They, with all their variant readings (which so far has been seen as a negative), were created to serve a living community, and this unique creation should be respected. They served an incredible variety of communities and traditions and theologies: there was not single homogeneous Christianity early on. And these texts are the reflection of this diversity and fluidity of tradition that was early Christianity.
} 
through: can this text be used with integrity in constructing a "theology"? Whose theology will it be? The theology of the compliers? Can it be used of a construct of a group or school, like for example the Johannine School? The text of John in Nestle-Aland is for sure not the one used in the community. There was no fixed original. It seems there were many variations, and very, very early on. How are we to tackle this problem? How useful is a text like Nestle-Aland ultimately?

If we ask questions in this manner we are throwing serious doubt on the textual critical endeavour of at least 250 years. And the ultimate question that accompanies these questions is: have we arrived at the death of New Testament textual criticism? If the task of New Testament textual criticism is seen narrowly as the quest to reconstruct the standard "original text" then the answer is a resounding YES. In that sense textual criticism is dead indeed. But if the task of textual criticism is defined in broader terms as "the study of the history of the text" (Delobel 2003:3), and if a concerted effort is made to establish some dialogue between a re-imagined textual criticism and other New Testament fields of research then textual criticism can indeed play a major role in enhancing and complementing and even leading in research where is was previously not considered to be of any consequence.

In the next section we will be looking at some implications and possibilities a reassessment of the role of textual criticism imply.

\section{A NEW UNDERSTANDING OF TEXTUAL CRITICISM}

If one takes the above observations seriously, it has some rather interesting implications, which in the end could lead to a re-definition, re-imagining and a revitalization of traditional New Testament Textual Criticism. Parker (1997:182) cautiously says that that the task of textual criticism may be to recover the original text, "but does not have to be", and we agree with this.

For too long textual criticism imprisoned itself in a very narrow understanding of its task and implications. Looking at textual criticism as something more than a quest for an elusive original, opens a large number of other possibilities of relevance for textual criticism. Without going into any detail, and not in any specific order of importance, if the observations made above are taken seriously, it could have some of the following implications:

- It will necessitate a re-evaluation of the New Testament Greek texts, like Nestle-Aland and the UBS text which was created by collating variables, and what they are and can actually be used for. We need to clearly define what we have in these texts and what role they ought to play in New Testament scholarship. Or, at the very least, we should be 
frank and ay exactly what these texts are, that they are modern, human compilation texts based on old manuscripts. Nothing more nothing less. These texts are definitely not the text which functioned anywhere in the early Christian church.

- A question, perhaps on a meta-level, that needs to be answered is the question of why there is and has been such an emphasis on an "original text" or a "standard text". Was it pressure from the side of churches, or academia, or power plays. This has not been investigated to any significant extent. If we can determine the underlying reasons for this, it could define the role of textual criticism in terms of the history of the development of the research, and not in terms of absolutes. We might find that we need textual criticism to be something completely different in this day and age from what it has been so far.

- It will necessitate the exploration of specific texts and basing interpretations on a specific text, rather than on Nestle-Aland or UBS. If a compilation text is not as useful as we have thought in the past, then the only way out is to use specific, individual texts as the basis for an interpretation. For example, for John we can use the text of Codex Bezae, or Codex Sinaiticus or Codex Alexandrinus.

- Different commentaries based on different texts will be needed. Commentaries we have are currently based on the compilation text, which we can now safely say did not exist. So commentators have commented and constructed theologies based on a text which is dubious. Does this imply that we will at best be able to write commentaries on specific texts? It would seem likely.

- A question regarding Bible translation also arises. On which text do we base Bible translations? If Nestle-Aland or UBS is not seen as approaching and original anymore, then it loses its claim to be the basis for any translation. Which text should then be used?

- If texts are seen as traditions and not only as carriers of tradition, this would bring the insights of textual criticism gleaned over centuries to bear on aspects of the history of early Christianity and the nature and development of disparate Christian communities and their individual traditions. There is a vast store of knowledge regarding textual history and traditions which scholars not involved directly with textual criticism 
know very little about. This knowledge can contribute immensely to other areas of study of the New Testament.

- With the wealth of textual variant material available, it would ultimately lead to a different way of "comparing" manuscripts. Instead of giving a text critical apparatus, texts could be printed next to each other so that all differences can be seen in context and not only in isolated instances. In our current depiction of variant in texts we tend to look at changes as trivial, because we see them one at a time. But if there was a way to depict the variants in a comprehensive fashion and see how many of these "trivial" changes there actually are, it will change the way we look at certain passages and interpret certain passages. It could reveal totally disparate interpretations in early Christianity of a single event. Parker (1997:188) says that the weight of a number of small variants can be an extremely significant.

- The nature of the various texts as texts, would also imply that various corpuses of New Testament material would have to be treated differently: For example in Paul's letters questions on whether or not they had an oral existence prior to a textual one, needs to be answered and accounted for in depicting and analysing the texts. Currently all New Testament texts are is treated the same way.

- The interfaces between orality and scribality needs to be looked at again. It seems that scribal difference goes back to oral difference, and the shift from orality to scribality is not from variability to fixity but rather from oral variability to scribal variability. The assumed great divide between orality and scribality is not that great.

- The general assumption is that the oral tradition ceased to exists when written texts appeared. Parker (1997:210) argues that this is not so:

One should think instead of an oral tradition extending unbroken from the lips and actions of Jesus, since people have never stopped talking about the things he said and did. Sometimes the oral tradition has been influenced by the written tradition and sometimes the influence has been in the opposite direction. The written and oral tradition have accompanied, affected and followed one another. 
- Because we have such a tiny proportion of texts which have existed one would need to carefully define the questions asked of the existing texts: are they representative of the totality of diversity that existed, or are they but a few examples of a much larger diversity within early Christianity?

- Seeing so many variants, the question must be asked: With how much variation in its tradition can a community cope with before it starts disintegrating? Qumran is, according to Parker, a community not so much concerned with variation.

- Everything that has been achieved by textual criticism is not totally obsolete and worthless, but its limitations should be kept in mind. But is can help us to understand relationships between developments and traditions, and can also help to shed light on the history of texts as well.

- One must also consider in all instances that in the majority of cases, variants are not due to chance. It is fact, also seen in the transmission of the Hebrew Bible and Masoretic texts, that copyists can very accurately copy manuscripts. If one would grant a larger number of intentional changes, this will have to be accounted for in the interpretation of any specific manuscript. There are reasons behind the intentional changes.

- In his book it becomes apparent that Parker is also interested in nomenclature. He argues that what we need terms to describe more accurately what we do and what is going on in the field. Current language reflects our singular focus on a "standard" text. This needs to change, and it is here that novel terms like "multiple originals" can begin to make inroads into old and obsolete understandings.

\section{CONCLUSION}

All of the above makes a rather strong argument for a programme in which traditional New Testament textual criticism can have a new lease on life and break out of the prison of many years for isolation and specialization. By looking at the aim of textual criticism not as searching for a non-existing "standard text", but as quest to use specialised manuscript and text knowledge to discover and recover something of the diversity and fluidity and vibrancy of early Christianity, we can perhaps rehabilitate the discipline of 
textual criticism in some way, so it again becomes a tool that can supplement and enhance the work of all New Testament scholars working in a variety of specialist areas.

\section{Works consulted}

Aland, B 2005. "Welche Rolle spielenTextkritik und Textgeschichte fur das Verstandnis des Neuen Testaments?" Presidential address, SNTS Annual Meeting. Halle, Germany, 6-9 August 2005.

Birdsall, J N 1999. Book review of Parker, D C 1997. The living text of the Gospels. Cambridge: Cambridge University Press. The Journal of Theological Studies 50(1), 275-288.

Clarke, K D \& Bales, K 1999. The construction of biblical certainty: Textual optimism and the United Bible Societies' Greek New Testament, in Petersen, W L (ed), Studies in the early text of the Gospels and Acts: The papers of the First Birmingham Colloquium on the Textual Criticism of the New Testament, 86-93. Atlanta, GA: Society of Biblical Literature.

Delobel, J 2002. The achilles' heel of New Testament Textual Criticism. Bijdragen 63(1), 3-21.

Ehrman, B D 2000. Text and tradition: The role of New Testament manuscripts in early Christian Studies. TC: A Journal of Biblical Textual Criticism 5, pars 1-62 (part 1), pars 1-64 (part 2).

Ehrman, B D 2006. Misquoting Jesus: The story of those who changes the Bible and why. New York: HarperSanFrancisco.

Ellingworth, P 2000. Text, translation, and theology: The New Testament in the original Greek. Filologia Neotestamentica 13, 61-73.

Elliott, J K 1999. Book review of Parker, D C 1997. The living text of the Gospels. Novum Testamentum 41(1), 176-181.

Elliott, J K 1999. Five new Papyri of the New Testament. Novum Testamentum 41(3), 209-213.

Epp, E J 1999. The multivalence of the term "Original Text" in New Testament Textual Criticism. Harvard Theological Review 92(3), 245-281.

Epp, E J \& Fee, G D (eds) 1981. New Testament Textual Criticism: Its significance for exegesis: Essays in honour of Bruce M Metzger. Oxford: Clarendon.

Epp, E J \& Fee, G D 1993. Studies in the theory and method of New Testament Textual Criticism. Grand Rapids, MI: Eerdmans. (Studies and Documents 45.)

Harvey, A E 1981. Book review of Parker, D C 1997. The living text of the Gospels. Theology 101, 41-142.

Head, P M 2000. Some recently published NT Papyri from Oxyrhynchus: An overview and preliminary assessment. Tyndale Bulletin 51(1), 1-16. 
Head, P M 2002. Book review of Parker, D C 1997. The living text of the Gospels. Evangelical Quarterly 74(1), 359-361.

Kelber, W 2005. Orality, scribality and oral-scribal interfaces. Jesus Tradition - Gospels: Review and present state of research. Paper presented at the SNTS Annual Meeting, Halle, Germany, 6-9 August 2005.

Mathews, S F 2000. The Greek New Testament. Bible Today 38(5), 306-309.

Mathews, S F 2000. The Syriac versions of the Bible. Bible Today 38(6), 374377.

McKendrick, S \& O'Sullivan, O A (Eds) 2003. The Bible as Book: The transmission of the Greek Text. London: British Library.

Metzger, B M 1968. The text of the New Testament: Its transmission, corruption and restoration, 2nd ed. Oxford: Clarendon.

Parker D C 1992. Codex Bezae. An early Christina manuscript and its text. Cambridge: Cambridge University Press.

Parker D C 1997. The living text of the Gospels. Cambridge: Cambridge University Press.

Parker D C 2000. Manuscripts of the Gospels in the electronic age. Restoration Quarterly 42(4), 221-231

Parker D C \& Amphoux C-B (Eds) 1996. Codex Bezae. Studies form the Lunel Colloquium June 1994. Leiden: Brill. (New Testament Tools and Studies 22.)

Silva, M 2000. Book review of Parker, D C 1997. The living text of the Gospels. The Westminster Theological Journal 62(1), 295-302.

Snyder, G H 2000. Teachers and texts in the ancient world: Philosophers, Jews and Christians. London: Routledge.

Trobisch, D 2000. The first edition of the New Testament. New York: Oxford University Press.

Vinson, R B 1999. Book review of Parker, D C 1997. The living text of the Gospels. Journal of Biblical Literature 118(1), 161-163. 